\title{
Pemanfaatan Aplikasi Perkantoran untuk Pembuatan Presentasi pada Lembaga Kursus Kecantikan Anggota HISPPI Kota Tegal
}

\author{
Ida Afriliana ${ }^{1 *}$, Jatmiko Indriyanto ${ }^{1}$, Eko Budihartono ${ }^{1}$, Arif Rakhman, Nurohim ${ }^{1}$ \\ ${ }^{1}$ Politeknik Harapan Bersama, Jl. Mataram No.9 Tegal, Jawa Tengah, Indonesia, 52142 \\ *Email Korespondensi: idaafriharahap@gmail.ac.id
}

\begin{abstract}
Abstrak
Kegiatan pengabdian masyarakat kepada anggota Himpunan Seluruh Pendidik dan Penguji Pendidikan Seluruh Indonesia (HISPPI) ini merupakan pengabdian masyarakat yang kedua kalinya. Pada kesempatan ini pengabdian masyarakat ini membahas pemanfaatan aplikasi perkantoran khususnya Microsoft Power Point untuk pembuatan materi presentasi anggota HISPPI dalam mendemontrasikan cara merias pengantin di Lembaga Kursus Kecantikan. Sebagian besar anggota HISPPI tidak mempunyai latar belakang komputasi, bahkan ada yang buta dengan penggunaan Ms.Office. Padahal setiap acara yang diselenggarakan oleh Lembaga Kursus, diharuskan menggunakan materi presentasi dimana isi presentsi tersebut adalah langkah-langkah tata rias yang langsung dipraktikkan kepada model. Maka para anggota HISPPI dituntut untuk dapat membuat materi presentasi yang dipersembahkan dengan praktik kepada model tanpa harus dioperasikan oleh operator yang mengoperasikan komputer. Pengabdian masyarakat ini dilakukan pada tanggal 1-3 Maret 2019 diikuti oleh anggota HISPPI yang kebanyakan para-para ibu pemilik Salon. Pengabdian masyarakat ini dilakukan dengan cara pendampingan langsung pada pembuatan materi presentasi dengan luaran adalah video presentasi. Hanya 10\% anggota HISPPI yang memiliki latar belakang komputer, dan 90\% masih buta terhadap pembuatan materi presentasi. Setelah dilakukan pengabdian masyarakat ini 60\% anggota HISPPI telah membuat materi presentasi berupa video presentasi.
\end{abstract}

Kata kunci: Pengabdian masyarakat; HISPPI; aplikasi perkantoran

\begin{abstract}
Community service activities to members of Himpunan Seluruh Pendidik dan Penguji Pendidikan Seluruh Indonesia (HISPPI) are the second time community service. On this occasion the community service discussed about application Microsoft office for presentation of HISPPI member to demonstrating how to make bridal make up at the beauty course Instutite. Most of HISPPI member do not have a computing background, some are even can operate the presentation tools like Microsoft power point but they can't make presentation with this tool. Every event done by Course Institute, is required to use presentation step by step to make bridal make up followed by practice to make up the model. So the members of HISPPI are required to be able to make presentation material that presented with practice to the model without having operated by the operator sho operates by the computer. This community service was carried out on March 1 to 3, 2019, followed by member of the HISPPI, who were mostly beauty salon owner. At this moment, the member of community service can make video presentation by Microsoft Power point. Just 10\% of member HISPPI can operate computer, but after this moment $60 \%$ of member HISPPI have made video presentation by Ms.Power point.
\end{abstract}

Keywords: Community service; HISPPI; office application.

Format Sitasi: Afriliana, I., Indriyanto, J., Budihartono, E., Rakhman, A., \& Nurohim. (2020). Pemanfaatan Aplikasi Perkantoran untuk Pembuatan Presentasi pada Lembaga Kursus Kecantikan Anggota HISPPI Kota Tegal. Jurnal Solma, 09(2), 436-443. Doi: http://dx.doi.org/10.22236/solma.v9i2.3338

Diterima: 28 Maret 2020 | Revisi 08 September 2020 | Dipublikasikan: 30 Oktober 2020


(C) 2020 Oleh authors. Lisensi Jurnal Solma, LPPM-Uhamka, Jakarta. Artikel ini bersifat open access yang didistribusikan di bawah syarat dan ketentuan Creative Commons Attribution (CC BY) license. (http://creativecommons.org/licenses/by/4.0/).

\section{PENDAHULUAN}

Perkembangan teknologi pada era milenia ini sangat pesat sekali, dan hal ini terjadi menyeluruh kepada seluruh lapisan masyarakat dan meliputi segala bidang kehidupan. Perkembangan teknologi informasi ini sangat mempengaruhi kehidupan masyarakat, terutama pada kemajuan pola pikir masyarakat sampai gaya hidup. Hal ini memiliki dampak positif bagi perkembangan komunikasi dan informasi, dimana informasi bisa didapat secara mudah hanya dengan jendela informasi yang terhubung dengan internet, baik itu yang diakses melalui smartphone ataupun komputer atau laptop. Semua kegiatan dalam kehidupan masyarakat telah beralih dari konvensional menjadi komputerisasi. Menurut Setiawan (2018) kemajuan dibidang komputerisasi merupakan awal dari perkembangan teknologi informasi. Cara pandang ilmu komunikasi, tekonologi komunikasi merupakan suatu sistem makro yang di dalamnya meliputi teknologi telekomunikasi, teknologi elektronika, dan Teknologi informatika (Liliweri, 2011; Setiawan, 2018).

Kegiatan usaha yang dilakukan masyarakat balesari telah memberikan nilai tambah bagi penduduk berupa pendapatan yang dapat digunakan untuk memenuhi kebutuhan hidupnya (menyambung hidup), produksi yang dilakukan ada yang berdasarkan pesanan dan belum banyak UKM yang membangun akses pasar baru, sehingga omset produksinya masih terbatas (Juliprijanto et al., 2017). Usaha Mikro, Kecil, dan Menengah (UMKM) dalam perekonomian nasional memiliki peran yang penting dan strategis. Kondisi tersebut dapat dilihat dari berbagai data yang mendukung bahwa eksistensi UMKM cukup dominan dalam perekonomian Indonesia (Suryani et al., 2019).

Salah satu perkembangan yang terjadi di Indonesia adalah makin banyaknya jumlah Lembaga Kursus Pelatihan (LKP). Menurut Syah et al., (2019) Lembaga Kursus Pendidikan (LKP) merupakan lembaga pendidikan yang bergerak dalam pelatihan aplikasi perkantoran. Lembaga Kursus Pelatihan ini merupakan suatu lembaga yang membantu di bidang ketrampilan sumber daya manusia yang memiliki ketrampilan khusus, baik LKP pada bidang komputer, tataboga ataupun tata rias kecantikan. Landasan hukum tentang LKP di Indonesia terdapat pada Undang-Undang No.20 tentang Sistem Pendidikan Nasional pasal 26 yang membahas Pendidikan Non-Formal, ayat empat (4) tahun 2003. Pada pasal (5) disebutkan bahwa Kursus dan pelatihan diselenggarakan bagi masyarakat yang memerlukan bekal pengetahuan, ketrampilan, kecakapan sikap untuk mengembangkan diri, mengembangkan profesi, bekerja, usaha mandiri, dan/atau melanjutkan ke jenjang yang lebih tinggi. Selain itu kembali diperlengkap pada pasal 103 ayat (1) PP No.17 pada tahun 2010 yang membahas tentang pengelolaan dan penyelenggaraan pendidikan bahwa kursus dan pelatihan diselenggarakan bagi masyarakat dalam rangka untuk mengembangkan kepribadian profesional dan untuk meningkatkan kompetensi vokasional dari peserta didik kursus. Program-program yang dapat dilaksanakan oleh lembaga kursus pelatihan seperti yang tertuang dalam pasal 103 ayat (2) Peraturan Pemerintah No.17 tahun 2010 yakni tentang pengelolaan dan penyelenggaraan pendidikan adalah antara lain sebagai berikut (1) 
Pendidikan kecakapan hidup; (2) Pendidikan kepemudaan; (3) Pendidikan pemberdayaan perempuan; (4) Pendidikan keaksaraan; (5) Pendidikan ketrampilan kerja; (6) Pendidikan kesetaraan dan/atau; (7) Pendidikan nonformal lain yang diperlukan masyarakat.

Menurut Badan Pusat Statistik (2016) hasil data sensus ekonomi pada tahun 2016 bahwa usaha/perusahaan pendidikan di Indonesia mencapai 619.947 usaha/LKP. Hal ini setara dengan 2,32\% dari jumlah usaha/perusahaan di Indonesia. Usaha/perusahaan pendidikan yang dimaksudkan dalam sensus ekonomi ini adalah mencakup kegiatan pendidikan pada berbagai tingkatan dan untuk berbagai pekerjaan, baik lisan ataupun tertulis seperti halnya cara berkomunikasi. Menurut Undang-Undang Republik Indonesia No. 20 Tahun 2003 Pulau Jawa menjadi daerah dengan jumlah usaha LKP terbanyak, yang mencapai 350.665 atau 56,56\% dari total usaha yang ada di Indonesia. Sedangkan ada 13.677 usaha pendidikan di wilayah timur Indonesia (Departemen Pendidikan Nasional, 2003). Hal ini terlihat bahwa tingginya proporsi usaha/perusahaan di Pulau Jawa yang dipengaruhi oleh jumlah penduduk Pulau Jawa yang berumur produktif lebih banyak dibandingkan pada Pulau lainnya. Adapun secara skala kategori dibagi atas usaha mikri dan kecil atau UMK pada industri pendidikan mencapai (Kemendikbud, 2012). 607.283 atau setara dengan 97,96\% dan kategori menengah (Badan Pusat Statistik, 2016).

Berdasarkan data Direktoran Pembinaan Kursus dan Pelatihan Kementrian Pendidikan dan Kebudayaan pada tahun 2011, jumlah LKP di Indonesia sebanyak 16.353, dengan tren yang meningkat yakni pada bulan April 2017 tercatat sebanyak 29.283 yang masih dalam proses pendaftaran. Dengan kata lain bahwa pertumbuhan 10,2\% mulai dari tahun 2011 hingga tahun 2017. Kenaikan jumlah LKP ini juga terlihat di Kota Tegal, sayangnya penerapan kemajuan teknologi pada LKP di Kota Tegal belum dilakukan secara efektif, terlihat dari pengelolaan LKP dan cara penyajian materi pada LKP tersebut (Kemendikbud, 2012).

Himpunan Seluruh Pendidik dan Penguji Pendidikan Seluruh Indonesia (HISPPI) merupakan suatu wadah bagi pemilik LKP, yakni organisasi kemasyarakatan non politis yang diselenggarakan oleh masyarakat praktisi dan pecinta pendidikan non formal (Indriyanto, J., \& Afriliana., 2019). Hampir semua pemilik LKP di Kota Tegal terhimpun menjadi anggota HISPPI. Pada pengabdian masyarakat yang dilakukan kepada anggota HISPPI Kota Tegal pada semester ganjil tahun akademik 2017/2018 didapat beberapa hasil PKM, salah satu diantaranya adalah untuk dilakukan peningkatan kompetensi anggota HISPPI untuk mengoperasikan komputer. Dengan latar belakang tersebut maka pengabdian masyarakat ini dilakukan kedua kalinya untuk anggota HISPPI dengan mengambil judul PKM ,’Peningkatan kompetensi anggota HISSPI dalam memanfaatkan aplikasi perkantoran bagi performa anggota HISPPI”.

Tujuan pengabdian masyarakat ini adalah untuk meningkatkan kompetensi anggota HISPPI dalam mendemontrasikan praktik kecantikan yang dilakukan dengan model kecantikan sekaligus menggunakan alat bantu presentasi berupa video presentasi. Video presentasi ini dibuat menggunakan Microsoft Powerpoint dengan memainkan tools animasi dan waktu durasi yang disesuaikan dengan proses make up kecantikan yang sedang didemonstrasikan. Sehingga para pemilik salon dapat melakukan presentasi tanpa memerlukan operator komputer. 


\section{MASALAH}

Permasalahan yang dihadapi oleh anggota HISPPI adalah keterbatasan kemampuan dalam mengoperasikan komputer karena pemilik LKP ini sebagian besar adalah pemilik salon yang memiliki latar belakang bukan dari bidang komputer, walapupun ada bebarapa anggota yang telah memiliki LKP dalam bidang komputer, tetapi hanya berkisar 5-10\% saja. 90\% sisanya merupakan para pemilik salon dengan latar belakang yang beragam, ada yang pernah mengoperasikan komputer bahkan ada yang jarang sekali menggunakan komputer atau laptop, padahal untuk saat ini sangat diperlukan ketrampilan dalam membuat materi presentasi menggunakan Microsoft Power point.

Selama ini pembuatan materi presentasi (dalam bentuk power point) tidak dibuat oleh para pemilik LKP tetapi dibuatkan oleh orang lain yang tidak memiliki kemampuan merias sehingga kadang pemilik salon merasa kesulitan untuk menuangkan materi kedalam bentuk presentasi. Dan juga saat demontrasi dengan model kecantikan, pemateri harus juga mengoperakan komputer untuk menjalankan file presentasi, maka ini tidak efektif. Teknologi informasi berbasis computer mampu meningkatkan efisiesi dan efektifitas kinerja (Irmayani \& Sudirman, 2019). Menurut Rokhman et al., (2018) pemanfaatan fitur yang maksimal dapat membantu mempermudah dan mempercepat dalam menangani pengelolaan administrasi.

Oleh karena itu kegiatan pengabdian masyarakat ini dilakukan guna memberikan kemampuan kepada pemiliki LKP untuk dapat membuat materi presentasi menggunakan tools microsoft powerpoint dengan output presentasi berupa video sehingga pemateri tidak perlu lagi operator komputer.

\section{METODE PELAKSANAAN}

Metode yang digunakan adalah simulasi penggunaan Microsoft Power point dimana pelaksanaan pengabdian masyarakat ini mempraktikkan langsung pembuatan materi presentasi. Dalam pembuatan materi presentasi ini dilakukan pendampingan oleh tim pengabdian masyarakat yang terdiri dari sejumlah 5 dosen kepada semua peserta pengabdian masyarakat ini. Sebuah kasus pembuatan materi presentasi dilakukan oleh para anggota HISPPI. Hasil dari presentasi ini didapatkan sebuah video presentasi.

Pengabdian masyarakat ini dilaksanakan pada tanggal 1-3 Maret 2019 yang bertempat pada Salon Tiara, Jl. Teuku Umar No. 184 , Kecamatan Tegal Selatan, Tegal. Acara pengabdian masyarakat ini dilakukan bertepatan dengan pertemuan rutin tiap bulan anggota HISPPI.

Dari kegiatan yang dilakukan daya serap anggota HISPPI mencapai 60\% dimana sebagian anggota dapat mengikuti materi ini dengan mudah tetapi ada juga yang sangat lambat dapat menerima materi ini. Sasaran tujuan dapat tercapai pada pengabdian masyarakat ini yakni semua anggota HISPPI dapat membuat satu produk video presentasi.

\section{HASIL DAN PEMBAHASAN}

Penggunaan Microsoft powerpoint mungkin sering digunakan oleh para pengguna seperti pada bidang pendidikan dari level sekolah tingkat pertama sampai tingkat perguruan tinggi. Srimaya (2017) menunjukan bahwa powerpoint efektif untuk meningkatkan motivasi 
dan hasil belajar. Tetapi bagi pemilik LKP yang sebagian besar memiliki latar belakang kecantikan, hal ini merupakan hal baru, maka pengenalan tentang laptop dari hardware dan software diberikan pada pengabdian masyarakat ini.

Materi yang diberikan antara lain :

1. Pendahuluan yakni pengenalan laptop serta fungsi-fungsi tools yang ada. Termasuk pengenalan alat perekam data seperti penyimpanan ke flashdish atau gogle drive.

2. Materi penggunaan Ms.Word secara sekilas dan fungsinya.

3. Materi penggunaan Ms.xcel secara sekilas dan fungsinya.

4. Materi Ms.Powerpoint secara implementatif. Yakni pengenalan semua tools pada Ms.powerpoint termasuk tahap-tahap pembuatan materi presentasi dari:

a) Membuat Judul Presentasi

b) Membuat menu presentasi yakni tahapan pada make up pengantin.

c) Menggunakan tools animasi untuk mengatur lama durasi slide presentasi yang tampil harus disesuaikan dengan lama pengerjaan demontrasi kecantikan yang dilakukan.

d) Penyimpanan materi presentasi dengan bentuk video presetasi.

Kendala yang dihadapi pada pengabdian masyarakat ini adalah karena perbedaan kemampuan anggota HISPPI yang beragam, maka pelatihan ini dilakukan dengan pendekatan yang sesuai, apalagi ada beberapa dari anggota HISPPI yang sudah berumur maka perlu kesabaran dalam pelatihan tersebdut. Komunikasi juga mengalami sedikit Kendala namun dapat diselesaikan dengan baik oleh tim pengabdian masyarakat.

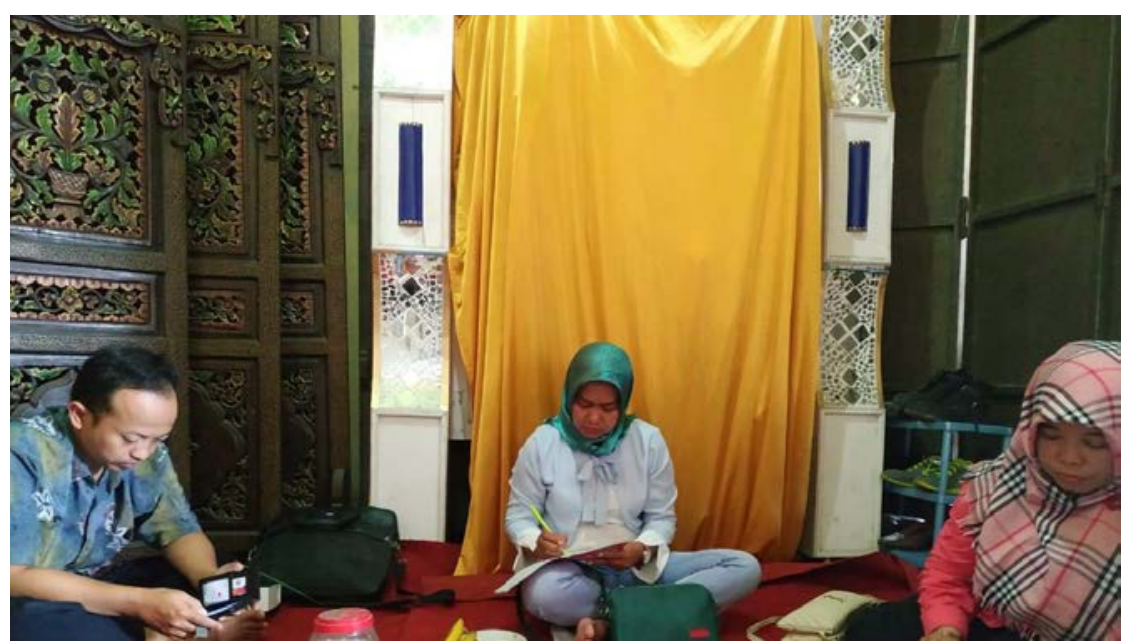

Gambar 1. Suasana Pelaksanaan PKM

\section{Pemetaan daya serap anggota HISPPI}

Setelah pelaksanaan pengabdian masyarakat, dilakukan pemetaan daya serap dari anggota HISPPI tentang materi ini. Hasil yang didapatkan adalah sebagai berikut:

Tabel 1. Pemetaan Kehadiran Peserta Dalam PKM

\begin{tabular}{cc}
\hline Jumlah anggota HISPPI & 40 orang \\
Jumlah anggota HISPPI yang hadir & 24 orang \\
Persentase kehadiran & $60 \%$ \\
\hline
\end{tabular}


Kehadiran tidak dapat tercapai 100\% karena memang kendala waktu pelaksanaan yang dihadapi, masing-masing anggota HISPPI ada yang sedang bertugas untuk merias pengantin pada saat pelaksanaan pengabdian masyarakat ini. Solusi untuk hal ini maka dibuat grup whatapps sehingga dapat terjalin komunikasi yang berkesinambungan untuk membahas materi ini.

Adapun daya serap anggota HISPPI terhadap materi yang diberikan seperti terlihat pada Gambar 2.

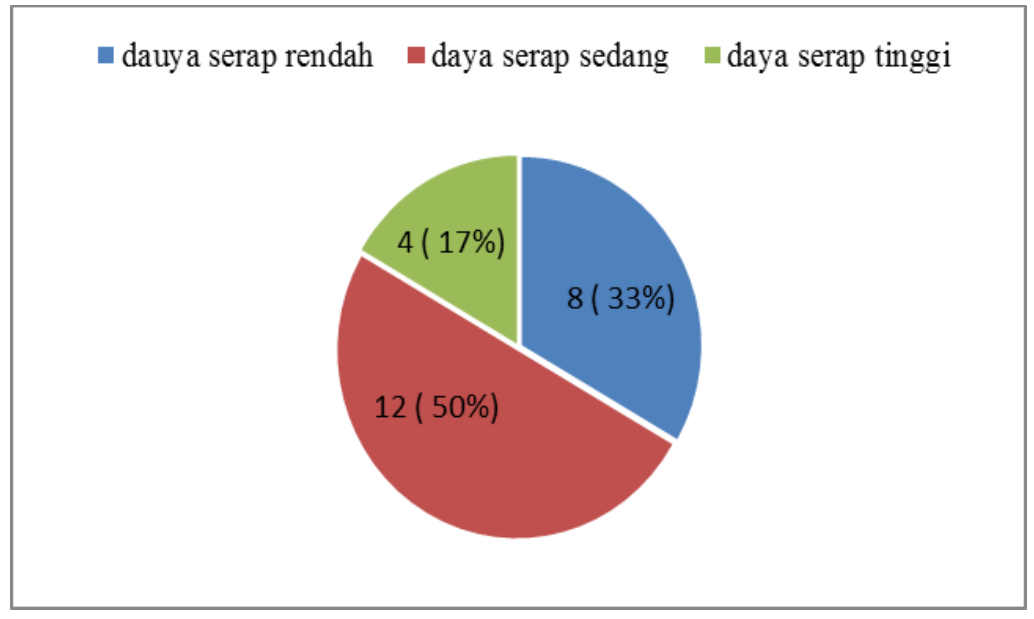

Gambar 2. Grafik Pemetaan Daya Serap

Walaupun ada sebagian yang masih rendah daya serap materi tetapi semua materi dapt tersampaikan dengan baik. Seperti terlihat pada gambar 2 bahwa 50\% peserta dapat menyerap materi dengan cukup atau daya serap sedang, 33\% peserta memiliki daya saing rendah dan $17 \%$ memiliki daya saing yang tinggi atau sangat baik. Menurut Nurhidayati et al., (2019) kegiatan pelatihan membuat bahan ajar power point ini menunjukkan bahwa dapat meningkatkan keterampilan para guru 109 MTs di Kabupaten Bojonegoro Asrori \& Ahsanuddin (2015) media power point dapat digunakan sebagai alat presentasi yang menarik. Media power point juga menggabungkan dan mensinergikan semua media yang terdiri dari teks, grafis, foto, video, animasi, musik, narasi, dan interaktivitas yang diprogram berdasarkan teori pembelajaran (Hamadin, 2015).

\section{KESIMPULAN}

Seperti yang telah dipaparkan dalam pembahasan diatas bahwa meskipun latar belakang anggota HISPPI bukan dari komputer dan memiliki tingkatan yang berbeda tetapi semua materi dapat tersampaikan dengan baik dan menghasilkan luaran adalah video presentasi untuk meningkatkan performa demontrasi kecantikan berbasis multimedia. Pengabdian masyarakat yang akan dilakukan selanjutnya adalah memberikan pelatihan untuk penggunaan komputer pada bidang pemasaran misalnya pelatihan desain grafis untuk membuat logo menggunakan tools yang sederhana.

Tujuan pengabdian ini telah tercapai dengan baik, yakni menigkatkan kemampuan anggota HISPPI dalam pemanfaatan microsoft office, khususnya power point untuk 
mempresentasikan materi, baik dalam bentuk slide presentasi atau dalam bentuk video presentasi.

\section{UCAPAN TERIMA KASIH}

Ucapan terima kasih kepada pihak P3M Politeknik Harapan Bersama yang telah memberikan kesempatan kepada para dosen untuk membuka kesempatan hibah pengabdian masyarakt pada periode semester ganjil tahun 2018/2019. Terima kasih kepada semua pengurus HISPPI yang telah memberikan kesempatan kepada tim pengabdian masyarakat untuk dapat berbagi ilmu pengetahuan dibidang komputer serta telah bekerja sama dengan baik.

\section{DAFTAR PUSTAKA}

Asrori, I., \& Ahsanuddin, M. (2015). Media Pembelajaan Bahasa Arab: dari Kartu Sederhana sampai Web Penjelajah Dunia. VC Bintang Sejahtera Press.

Badan Pusat Statistik. (2016). Sensus Ekonomi 2016. https://se2016.bps.go.id/umkumb/

Departemen Pendidikan Nasional. (2003). Undang-Undang Nomor: 20 Tahun 2003 Tentang Sistem Pendidikan Nasional. Depdiknas.

Hamadin. (2015). Pengembangan Media Pembelajaran Interaktif Berbasis TIK Dengan Pendekatan Saintifik. Journal of Physics Learning, 3(2), 51-62.

Indriyanto, J., \& Afriliana., I. (2019). Peningkatan Kompetensi Anggota HISPPI Kota Tegal dalam Penggunaan Aplikasi Berbasis Android. Jurnal Pengabdian Masyarakat Progresif Humanis Brainstorming, 13-17.

Irmayani, \& Sudirman, A. M. (2019). Pengembangan Sumber Daya Manusia melalui Pelatihan Microsoft Office pada Aparat Desa di Kecamatan Lamasi Timur Kabupaten Luwu Provinsi Sulawesi Selatan. Abdimas Toddopuli: Jurnal Pengabdian Pada Masyarakat, 1(1), 20-27.

Juliprijanto, W., Sarfiah, S. N., \& Priyono, N. (2017). Diskripsi dan Permasalahan Pelaku Usaha Kecil Menengah (UKM) (Studi Kasus Ukm di Desa Balesari, Kecamatan Windusari). Jurnal REP (Riset Ekonomi Pembangunan), 2(1), 77-90. https://doi.org/10.31002/rep.v2i2.224

Kemendikbud. (2012). Laporan Akuntabilitas Kinerja Kementrian Pendidikan dan Kebdayaan Tahun 2011. Kemendikbud.

Liliweri, A. (2011). Komunikasi Serba Ada Serba Makna. Prenada Media Group.

Nurhidayati, Asrori, I., Ahsanuddin, \& Dariyadi, M. H. (2019). Pembuatan Media Pembelajaran Berbasis Powerpoint dan Pemanfaatan Aplikasi Android untuk Guru Bahasa Arab. Jurnal Karinov, 2(3), 181-184.

Rokhman, M. M., Wibowo, A. S., Pranoto, A. Y., \& Widodo, A. K. (2018). Pelatihan Pemanfaatan Microsoft Office Pada Staf Pengajar Di SMPLBN (Sekolah Menengah Pertama Luar Biasa Negeri) Kota Malang. Jurnal MNEMONIC, 1(1). http://eprints.itn.ac.id/id/eprint/3340

Setiawan, D. (2018). Dampak Perkembangan Teknologi Informasi dan Komunikasi 
Terhadap Budaya. $\quad$ SIMBOLIKA, 4(1), 62-72. https://doi.org/10.31289/simbollika.v4i1.1474

Srimaya, S. (2017). Efektivitas Media Pembelajaran Power Point Untuk Meningkatkan Motivasi dan Hasil Belajar Biologi Siswa. Jurnal Biotek, 5(1), 53-68.

Suryani, L., Waliulu, Faisal, R., Murniyasih, \& Ery. (2019). Pengembangan Aplikasi Sistem Pendukung Keputusan Berbasis Android dengan Menggunakan Metode Analitycal Hierarchy Process (AHP) untuk Menentukan Prioritas Pengembangan Usaha Kecil Menengah di Kota Sorong. Jurnal Elektro Luceat, 5(2), 1-15.

Syah, A. Z., Ramdhan, W., Hasanah, U., \& Yesputra, R. (2019). Pelatihan Pembuatan Media Pembelajaran Berbasis Power Point Pada Lembaga Kursus Pendidikan (LKP) Mandiri Computer. Jurdimas (Jurnal Pengabdian Kepada Masyarakat) Royal, 2(2), 139-144. https://doi.org/10.33330/jurdimas.v2i2.372 